\title{
КОМПОНЕНТНА СТРУКТУРА ПІЗНАВАЛЬНОЇ АКТИВНОСТІ МАЙБУТНІХ УЧИТЕЛІВ МУЗИЧНОГО МИСТЕЦТВА
}

\author{
Завіруха Л. А. \\ викладач фортепіано \\ Луиький педагогічний коледж \\ проспект Волі, 36, Луцььк, Україна \\ orcid.org/0000-0002-9147-0977 \\ lili7466@ukr.net
}

\begin{abstract}
Ключові слова:
пізнавальна активність, структура, компоненти, майбутній вчитель музичного мистеитвва.
\end{abstract}

У статті розглянуто актуальну педагогічну проблему, пов'язану 3 розвитком компонентів структури пізнавальної активності майбутніх вчителів музичного мистецтва. За результатами аналізу структури пізнавальної активності виявлено та охарактеризовано провідні із зазначених компонентів: стимуляційно-мотиваційний, змістовноопераційний, контрольно-рефлексивний та самостійно-творчий.

Встановлено, що стимуляційно-мотиваційний компонент є стрижневим у формуванні пізнавальної активності суб'єктів навчання. Він визначається характером навчальної діяльності, сформованістю іiі структурних елементів та взаємодією в процесі навчання, змістом навчання; характером мотивів навчання, пізнавальними потребами та інтересами, особливостями емоцій, що супроводжують процес навчання.

Наступним компонентом пізнавальної активності майбутніх педагогів визначено змістовно-операційний, який полягає у збагаченні навчальної інформації та визначається сформованістю активно-перетворюючого ставлення студентів до власної навчальної діяльності, активізацією усіх пізнавальних процесів та пошуковою активністю.

Встановлено, що контрольно-рефлексивний компонент сприяє формуванню адекватної самооцінки у студентів та передбачає контроль за процесом власної навчально-виконавської діяльності, аналіз та корекцію їі результатів. Однак важлива роль тут відводиться викладачу, який грамотно та систематично залучає студентів до самоконтролю, самоаналізу та самооцінки.

Наступним i найвищим компонентом формування пізнавальної активності студентів визначено самостійно-творчий. Він передбачає уміння студентів самостійно вирішувати навальні-пізнавальні завдання, застосовувати нестандартні підходи до їх розв'язання, самостійно підбирати форми, прийоми і засоби навчання.

Зазначимо, що взаємозв'язок наведених компонентів виразно проявляється в навчально-виконавській діяльності та сприяє ефективному формуванню пізнавальної активності майбутніх педагогів. Визначено перспективи подальших наукових досліджень у теоретичному обгрунтуванні педагогічних умов формування пізнавальної активності майбутніх вчителів музичного мистецтва. 


\title{
THE COMPONENT STRUCTURE OF THE COGNITIONAL ACTIVITY OF THE FUTURE READERS IN THE MUSIC ART
}

\author{
Zavirukha L. A. \\ Lecturer of Piano \\ Lutsk Pedagogical College \\ Voli Avenue, 36, Lutsk, Ukraine \\ orcid.org/0000-0002-9147-0977 \\ lili7466@ukr.net
}

Key words:

cognitive activity, structure, components, future music teacher.
The article considers an actual pedagogical problem related to the development of components of the cognitive activity structure of future music teachers. According to the results of the analysis of the cognitive activity structure, the main of components were identified and characterized: stimulationmotivational, content-operational, control-reflexive and self-creative.

It is established that the stimulation-motivational component is the main one in the forming of cognitive activity of learning subjects. It is determined by the nature of educational activities, the formation of its structural elements and interaction in the learning process; the content of education; the nature of the learning motives; cognitive needs and interests, features of emotions that accompany the learning process.

The next component of cognitive activity of future teachers is defined as content-operational, which consists in enriching educational information and is determined by the formation of active-transforming attitude of students to their own educational activities, activation of all cognitive processes and search activity.

It is established that the control-reflexive component promotes the formation of adequate self-esteem in students, and provides control over the course of their own educational and executive activities, analysis and correction of its results. However, an important role is given to the teacher, who competently and systematically involves students in self-control, self-analysis and self-assessment. The next and highest component of the formation of students' cognitive activity is defined as self-creative. It provides students with the ability to solve their cognitive problems by themselves apply non-standard approaches to their solution, select forms, techniques and teaching aids.

It should be noticed, that the relationship of these components is clearly appeared in the educational and executive activities and promotes the effective formation of cognitive activity of future teachers. Prospects of further scientific researches in the theoretical substantiation of pedagogical conditions of the cognitive activity formation of future teachers of musical art are defined.
Постановка проблеми. Одним 3 основних завдань української освіти $\epsilon$ формування професійних та особистісних якостей майбутнього вчителя, розвиток здатності самостійно вчитися, планувати і активно вести навчально-пізнавальну діяльність, розширювати загальну і професійну компетентність. Саме тому важливим напрямом функціонування системи сучасної освіти є стимулювання та розвиток пізнавальної активності майбутніх педагогів. Від того, наскільки студенти будуть проявляти пізнавальну активність у навчанні, залежать ефективність та якість професійної підготовки майбутніх спеціалістів.
До проблеми формування та розвитку пізнавальної активності особистості зверталися у своїх дослідженнях В. Давидов, Л. Занков, П. Підкасистий, Т. Шамова, Г. Щукіна, В. Лозова та ін. Різні аспекти означеної проблеми розкриті в працях А. Алексюк, Ю. Бабанського, В. Вергасова, П. Лузана, О. Мачушник, О. Пиндик, Т. Темерівської та ін.

Проблема формування пізнавальної активності майбутнього вчителя є одним із важливих завдань теорії і практики музичної педагогіки. Окремі аспекти формування пізнавальної активності у сфері підготовки майбутнього вчителя 
музики знаходимо в працях В. Кузя, О. Олексюк, Г. Падалки, О. Ростовського, О. Щолокової та ін.

Чимало авторів, досліджуючи ті чи інші аспекти пізнавальної активності, підходять до цієї проблеми з особливих методологічних позицій, виділяючи різний набір компонентів досліджуваної якості особистості. Однак нині немає єдиного загальновизнаного розуміння компонентів структури пізнавальної активності.

3 огляду на це мета нашої статті полягає в тому, щоб основі аналізу психолого-педагогічних досліджень визначити та обгрунтувати структуру пізнавальної активності майбутніх вчителів музичного мистецтва.

Виклад основного матеріалу дослідження. Вивчаючи проблему пізнавальної активності особистості, варто зазначити, що загальним у дослідженнях психологів і педагогів $\epsilon$ те, що пізнавальна активність характеризується через діяльність і поза діяльністю не існує. Так, психологи загострюють увагу на таких складниках активності, як вибірковість, умотивованість, потреба, інтерес, старанність, ініціатива, інтенсивність діяльності. Педагоги поряд із готовністю особистості до активної діяльності вказують на дієвий характер ставлення суб'єкта до об'єкта пізнання, виділяють основні показники пізнавальної активності, такі як самостійність, саморегуляція, рефлексія діяльності, наполегливість, цілеспрямованість, творчість.

Пізнавальна активність виникає та формується у процесі навчальної діяльності, підносячи діяльність на новий рівень. Така навчальна діяльність супроводжується намаганням особистості власними силами розв'язати поставлене завдання, внаслідок чого виникають додаткова пошукова активність суб'єкта, прояв власної ініціативи, емоційні переживання.

Варто зазначити, що пізнавальна активність студентів реалізується через мотиваційну сферу особистості: під впливом пізнавальної потреби, мотивів, інтересів в процесі безпосередньої пізнавальної діяльності. Водночас, супроводжуючи будь яку самостійну дію, пізнавальна активність сприяє проявам творчої активності майбутніх вчителів музичного мистецтва.

Теоретичний аналіз наукової літератури дав змогу дійти висновку, що структура пізнавальної активності майбутніх вчителів музичного мистецтва передбачає наявність стимуляційно-мотиваційного, змістовно-операційного, контрольно-рефлексивного та самостійно-творчого компонентів.

Стимуляційно-мотиваційний компонент $\epsilon$ основним, адже мотивація пронизує усі структурні утворення особистості. Саме мотивація спонукає студента до активного засвоєння пев- ного обсягу музичного матеріалу. Формування навчальної мотивації - це відповідальний етап діяльності педагога. Глибокі, міцні, емоційно забарвлені та змістовні мотиви сприяють ефективності навчально-пізнавальних дій студентів і надають їм конкретну спрямованість.

Проблема мотивації в навчальній діяльності глибоко досліджувалась у працях Б. Ананьєва, Л. Божович, П. Гальперіна, Л. Добриніна, О. Ковальова, Г. Костюка, А. Маркової, Л. Матюшкіна, М. Алексєєвої та ін. На думку дослідників, показниками мотиваційної сфери особистості є пізнавальна потреба, пізнавальний інтерес, стимул, емоції, прагнення, спрямованість особистості на навчальну діяльність.

Оскільки процес задоволення потреб є цілеспрямованою діяльністю, потреби виступають джерелом активності особистості. Адже, «усвідомлюючи ціль як суб'єктивну потребу, людина переконується, що задоволення останньої можливо лише через іiї досягнення. Це дає ӥй змогу співвіднести свої суб'єктивні уявлення про потребу з іiі об'єктивним змістом, відшукуючи засоби досягнення цілі. Крім того, потреби виявляються в мотивах (бажаннях, інтересах), що спонукають людину до діяльності і стають формою виявлення потреб» [3, с. 287].

Проблема формування пізнавальних потреб знайшла глибоке обгрунтування в працях психологів (Б. Ананьєв, Л. Божович, П. Гальперін, М. Добринін, О. Матюшкін та ін.) і педагогів (М. Данилов, В. Ільїн, Д. Вількєєв, Ю. Шаров, І. Лернер, М. Махмутов).

Потреба в пізнавальній діяльності не виникає у студентів сама собою. Потребою, що зумовлює активність студентів, є пізнавальна задача, завдання, ситуація.

Так, на думку Н. Василенко-Несіної, основними потребами в музичній діяльності є: потреба в пізнанні, потреба у спілкуванні, потреба у творчості, самовираженні, потреба в переживанні цінності діяльності, потреба досягнення мети діяльності. Автор вважає, що розвиток та стимулювання означених потреб музично-педагогічної діяльності $є$ можливим лише за умови активної внутрішньої позиції студента, що передбачає суб' єкт-суб' єктивний підхід до організації занять [1, с. 92].

Варто зазначити, що реалізація потреби в пізнанні залежить від підготовки викладача до створення дидактичних і психологічних умов формування мотиваційної сфери особистості студента.

Поширеними мотивами пізнавальної активності є інтереси. Як і всі психічні властивості особистості, пізнавальний інтерес зароджується і розвивається в процесі пошуково-творчої діяль- 
ності. Досвід самостійної творчої діяльності сприяє переростанню простої цікавості і первинної допитливості в стійку рису особистості - пізнавальний інтерес.

Розглянемо, в чому ж полягає сутність пізнавального інтересу студентів у процесі навчальної діяльності.

Сформовані пізнавальні інтереси характеризуються наполегливістю i спрямованістю особистості у вивченні матеріалу й оволодінні різноманітними засобами пізнання, захопленістю процесом навчальної діяльності, єдністю пізнавальної активності й продуктивної діяльності, емоційно-пізнавальною зосередженістю в навчанні.

Однією 3 характеристик мотиву є його модальність, тобто емоційна забарвленість. У процесі діяльності педагог має створювати для студентів атмосферу емоційного комфорту, ситуації успіху. Позитивні емоції, що пов'язані з досягненням успіху, зазвичай сприяють підвищенню рівня пізнавальної активності суб'єктів навчання.

Перейдемо до розгляду ролі емоцій у мотивації навчання. Виховання правильної мотиваційної спрямованості, постановки цілей у майбутніх вчителів музики має супроводжуватися і впливом на емоційне ставлення студентів до навчання. Емоції, безсумнівно, мають мотивуюче значення в процесі навчання.

Специфіка емоцій, зазначав видатний радянський психолог А. Леонтьєв, полягає в тому, що вони відображають відношення між мотивами і можливістю успіху діяльності з реалізації цих мотивів.

Позитивні емоції, що виникають при оволодінні студентами прийомами самостійного здобування знань, новими способами вдосконалення своєї навчальної роботи, стимулюють їх інтерес до засвоєння нового навчального матеріалу. Тому викладач має впливати на формування емоцій, які активізують навчально-пізнавальну діяльність студентів.

Стимулювати навчально-пізнавальну діяльність студентів у сучасному розумінні означає спонукати їх до активної навчально-пізнавальної діяльності, підштовхувати до неї, заохочувати. Стимул навчання виникає тоді, коли потреба зустрічається із ситуацією свого задоволення. Тому стимул - це внутрішня активна спрямованість особистості, яка виявляється й активізується зовнішніми обставинами (стимуляторами). Зовнішні фактори (новизна навчального матеріалу, нетрадиційна форма навчання, навчання 3 комп’ютерною підтримкою) - це об'єктивні джерела стимулів активної навчально-пізнавальної діяльності суб'єктів навчання, або стимулятори [2, с. 196].
Загалом стимуляційно-мотиваційний компонент визначається такими моментами: характером самої навчальної діяльності студентів, сформованістю іï структурних елементів та взаємодією в процесі навчання; змістом навчання, характером мотивів навчання, пізнавальними потребами та інтересами, особливостями емоцій, що супроводжують процес навчання.

У структурі пізнавальної активності майбутніх вчителів музичного мистецтва одне 3 головних місць посідає змістовно-операційний компонент, який полягає в накопиченні певної начальної інформації.

До змістовно-операційного компонента належить система провідних знань і способів навчання, всі розумові операції (аналіз, порівняння, узагальнення, систематизація, абстрагування), пізнавальні процеси (відчуття, сприйняття, уявлення, пам'ять, мислення, уява), пов'язані з розумовим перетворенням у пізнанні.

Про сформованість розумових операцій та розумових умінь студентів свідчить здатність студента до самостійної перетворювальної мисленнєвої діяльності. Сформоване активно-перетворювальне ставлення особистості до пошукової та дослідницької діяльності забезпечує іiї активну спрямованість на інші види пізнавальної та творчої діяльності.

Пошукова пізнавальна активність студентів характеризується евристичною ініціативністю, самостійністю, знанням програмного матеріалу, вмінням здобувати нову інформацію, вирішувати нетипові завдання.

Змістовно-операційний компонент визначається сформованістю активно-перетворюючого ставлення студентів до власної навчальної діяльності, активізацією усіх пізнавальних процесів, пошуковою активністю.

Контрольно-рефлексивний компонент полягає у здатності до рефлексивного контролю своєї діяльності. Процес рефлексї - це нескінченний процес, який за позитивних умов, генерує пізнавальну активність особистості студента, зумовлює потребу в отриманні нових знань, умінь та навичок, поштовх до постійного професійного самовдосконалення, спричиняє формування адекватної самооцінки своєї діяльності, стійку потребу в самоосвіті, що має на меті істинно самостійну подальшу професійно-творчу самореалізацію в майбутній діяльності.

Рефлексивна здатність ефективно розвивається у процесі усвідомлення змістовно-ціннісної сутності музичних творів, постійного пошуку нових способів виконання. Контроль за ходом власної діяльності забезпечує критичність та самостійність мислення студента, підвищує ефективність його навчально-пізнавальної діяльності. 
Самостійно-творчий компонент характеризується найвищим ступенем пізнавальної активності студентів та проявляється в умінні вирішувати творчі пошукові задачі, застосовувати нестандартні підходи до вирішення поставлених освітніх завдань, у самостійному підборі форм, прийомів і засобів навчання.

Як один із видів навчально-пізнавальної діяльності самостійна робота передбачає розвиток активності, ініціативи, самоконтролю, рефлексивних умінь, музичного мислення, здатності до творчої діяльності, прояву пізнавальної надситуативності, яка характеризується самостійним та усвідомленим виходом студентів за межі поставленого педагогом завдання, розв'язання за власною ініціативою додаткових завдань.

Самостійна пізнавальна діяльність здійснюється за наявності в студента гностичних мотивів, інтелектуальної активності, тривалої уваги, перманентного сприйняття, яке переходить у спостереження та формує спостережливість. Вона забарвлена почуттями та вольовими зусиллями, підпорядкована цілям навчання; в ній виявляється вся особистість студента й формуються його самостійні пізнавальні можливості [4, с. 71].

Ефективність самостійної пізнавальної діяльності студентів зумовлена значною мірою її організацією. Від рівня організації цього процесу залежить формування інтересу до навчальної дисципліни, рівень пізнавальної активності, а отже, $\mathrm{i}$ постійного поповнення знань, формування умінь та навичок із відповідним виходом на професійну діяльність [4, с. 73].

Високий рівень самоконтролю дає змогу активізувати самостійність, покращити виконавську самопідготовку і спрямовувати студентів на вирішення професійних завдань: коригувати власну гру на інструменті, регулювати емоційний стан під час сценічного виконання творів.

Найвищим проявом самостійної пізнавальної діяльності майбутніх учителів музики є вияв творчої активності.

На думку Т. Шамової, творча активність це вищий рівень пізнавальної активності, який характеризується інтересом і прагненням не тільки проникати глибоко в суть явищ та їх взаємозв'язків, але й знайти для цієї мети новий спосіб [5, с. 53].

Творчу активність можна сформувати, тільки стимулюючи потребу діяти самостійно, виявляти інтерес у процесі пошукової діяльності, розвивати здатність до рефлексії.

Зазначимо, що прояви творчої, самостійної активності, стійке прагнення до пізнання значною мірою сприяють розвитку пізнавальної активності майбутнього вчителя.

Отже, пізнавальна активність виступає як умова формування у студентів потреби в знаннях, оволодіння вміннями пізнавальної діяльності, самостійності, забезпечення глибини і міцності знань. До структурної організації цього феномена належать стимуляційно-мотиваційний, змістовно-операційний, контрольно-рефлексивний та самостійно-творчий компоненти. Взаємозв'язок цих компонентів виразно проявляється в навчальній діяльності. Перспективою подальших наукових досліджень вважаємо теоретичне обгрунтування педагогічних умов формування пізнавальної активності майбутніх вчителів музичного мистецтва.

\section{Література}

1. Василенко-Несіна Н.А. Формування мотивів музично-педагогічної діяльності майбутніх учителів музики. Теоретичні та методичні засади мистещької освіти : збірник матеріалів науково-методичного семінару. Чернівці : Зелена Буковина, 2007. С. 91-92.

2. Мойсеюк Н.С. Педагогіка : навч. посібник. 3-є вид. Київ, 2001. 607 с.

3. Петровский А.В., Ярошевский М.Г. Психология. Словарь. Москва : Политиздат, 1990. 494 с.

4. Солдатенко М.М. Теорія і практика самостійної пізнавальної діяльності. Монографія. Київ : НПУ імені М.П. Драгоманова, 2006. 198 с.

5. Шамова Т.И. Активизация учения школьников. Москва : Педагогика, 1982. 208 с.

\section{References}

1. Vasylenko-Nesina, N.A. (2007) "Formation of motives of musical and pedagogical activity of future music teachers", Teoretychni ta metoduchni zasady mystezkoi osvity [Theoretical and methodological principles of art education: collection materials of the scientific-methodical seminar], Chernivtsi: Zelena Bukovyna.

2. Moiseiuk, N.Ye. (2001) Pedahohika : navch. posib. [Pedagogy: a textbook]. 3rd ed. Kyiv.

3. Petrovskyi, A.V., Yaroshevskyi, M.H. (1993) Psykholohia: slovar [Psychology: a dictionary]. Moscow: Politizdat.

4. Soldatenko, M.M. (2006), Teoria i praktyka samostiinoi piznavalnoi dialnosti [Theory and practice of self cognitive activity]. Kyiv: Publishing House of the National Pedagogical University named after M.P. Dragomanov.

5. Shamova, T.I. (1982) Aktyvizatsija uchenia shkolnikov [Activation of training of schoolchildren]. Moscow, Pedagogika. 